\title{
3
}

\section{An international human rights approach to corruption}

\author{
Zoe Pearson
}

Corruption is a phenomenon that appears to be increasing throughout the world. It is a problem that affects both developed and developing countries to varying degrees, depending on the extent and type of corruption. There is a vast literature on the subject of corruption. Much of it approaches the problem from an economic or a political viewpoint, and the resulting analyses of the causes, effects and solutions to corruption reflect this approach. Corruption is viewed as having a deleterious effect on the economic growth and development of a country. This conclusion is generally accepted despite the limited empirical data. Corruption is also seen as a contributing factor to ongoing inequalities, whether in developed or developing countries.

It is important to extend the way in which corruption is analysed. It is argued here that current approaches that view corruption as exclusively an economic and political issue are inadequate and fail to give significance to the effect of corruption on people's lives and their rights. This chapter examines the effect of corruption on fundamental human rights. It argues that tolerance of corruption by states results in breaches of human rights and that existing international human rights mechanisms may therefore be useful in the fight against corruption. It does not propose the establishment of new human rights. Essentially, the fight against corruption and the fight for protection of human rights both rest on the need for accountable, representative government committed to equality and transparency.

\section{The current approach}

\section{General issues and approaches to corruption}

Corruption is a phenomenon that human societies have experienced and attempted to overcome for thousands of years (Alatas 1990; Morgan 1998). 
Alatas notes that the problem of corruption can be traced to the beginnings of humankind's social interaction and the development of social organisations. It is a problem that appears to be widespread. Despite the limited empirical evidence, most of the literature refers to corruption as being 'both pervasive and significant' throughout the world (Shleifer and Vishny 1993:599). It is important to emphasise that corruption is a worldwide phenomenon, experienced in both developed and developing countries. However, both the United Nations Development Programme (UNDP) and the World Bank note that the causes and effects of corruption vary from country to country, depending on the prevailing social, economic and political conditions (World Bank 1997b; UNDP 1999). Nye (1967:418) comments that while corruption is certainly not limited to developing countries, 'the conditions of [developing] countries are such that corruption is likely to have different effects than in more developed countries'.

While corruption and the campaigns against it are not new, the problem of corruption is emerging as an important global issue requiring global action. Glynn et al. comment that 'this decade is the first to witness the emergence of corruption as a truly political issue eliciting a global political response' (1997:7). Elliott, too, notes an increase in international action concerned with corruption this decade, with policies emerging to combat corruption from bodies such as the Organisation of American States (OAS), the International Chamber of Commerce, the World Bank (IBRD), the United Nations (UN), the International Monetary Fund (IMF), the World Trade Organization (WTO), and the Organisation for Economic Cooperation and Development (OECD) (Elliott 1997b:2-3). In addition, the growth of the non-governmental organisation Transparency International (TI) since its establishment in 1993 has been an important force in increasing the awareness of corruption as an international problem. Despite the limited empirical evidence on levels of corruption, the success and growth of international action against corruption indicates that there is real concern about corruption as an international issue.

The reasons for this increase in international awareness and action on corruption are varied. Commentators point to the increase in globalising tendencies as an important influence in the growth of awareness of corruption, with the increased interrelatedness of countries making corruption harder to hide (George et al. 1999). The end of the Cold War is also thought to have contributed to the emergence of corruption as an international issue (Glynn et al. 1997). Much of the literature discusses the increasing international integration in economic and trade arenas as important influences (Elliott 1997b; Joongi and Jong 1997). Other commentators point to the spread of values of democracy, and the increase in expectations of the accountability and 
transparency of states as influential (World Bank 1997a; Elliott 1997b). The increase in awareness of the importance of protection for human rights may also be a significant influence. The changing nature of the media in response to increased demands for transparency in the public arena, and the increased opportunities for communication due to advances in technology are also regarded as being important (Glynn et al. 1997; George et al. 1999). Glynn et al. believe that 'a new global standard appears to be taking shape in human consciousness, with potentially major ramifications for our institutions as well as our political and business lives' (1997:8).

\section{Definitions}

Definitions abound for corruption and nearly all mention the difficulties involved in formulating a definition. Gould (1991:467) notes that 'corruption has no single definition. It varies from region to region and remains largely contextual'. The World Bank (1997b) suggests that part of the reason for the difficulty in defining corruption lies in the complexity of the concept. Corruption is a phenomenon that may refer to many different human activities and behaviour in differing circumstances. As the causes and effects of corruption are different depending on the context of the country, it is perhaps not surprising that a single comprehensive definition that covers all the manifestations of corruption is difficult to formulate. As the Council of Europe notes, the result is that 'no precise definition can be found which applies to all forms, types and degrees of corruption, or which would be acceptable universally as covering all acts which are considered in every jurisdiction as contributing to corruption' (World Bank 1997b:20). The fact that corruption is studied from several different disciplines, including economics, law, sociology, political science and anthropology also contributes to the variety of definitions (Morgan 1998).

As a result of the difficulties of arriving at a universal definition, Morgan (1998) notes that much of the literature adopts a minimalist definition, concise and broad enough to be of use in most instances of corruption. The definition provided by the World Bank and also by Transparency International is an example of this, where corruption is defined as 'the abuse of public office for private gain' (World Bank 1997b:13; Transparency International website). Other institutions and authors have adopted similarly broad definitions (Morgan 1998:11-12). For the purposes of this chapter, such a broad definition of corruption will be adopted. It is worth noting that in most of these broad definitions, the focus is on corruption in the public sector, although there is recognition that corruption may also be present in the private sector. This may occur as a result of individuals engaging in corrupt behaviour within private companies for their own interest, and also as a 
result of individuals engaging in corrupt behaviour with public entities for their own private benefit. As the World Bank comments,

the problem of corruption lies at the intersection of the public and private sectors. It is a two-way street. Private interests, domestic and external, wield their influence through illegal means to take advantage of opportunities for corruption and rent seeking, and public institutions succumb to these and other sources of corruption in the absence of credible restraints (1997a:102).

A distinction is often drawn between grand corruption and petty corruption. While grand corruption involves high public officials making corrupt decisions on large public contracts, petty corruption is generally said to involve public servants obtaining small extra payments-sometimes known as 'speed money'from the public in return for the performance of their official duties (UNDP 1999). This chapter examines corruption as a systemic issue, and will thus consider the broader effects of corruption as a prevalent phenomenon, rather than concentrating on the differences between grand and petty corruption, both of which form a part of the larger picture of corruption within a society.

The broad definition can then be broken down further, distinguishing types of corruption by where it occurs (private or public sector), how it occurs (by extortion or consent), its intensity (high or low levels, depending on institutional mechanisms, governmental constraints and public tolerance of it), its prevalence (isolated or systemic occurrences), and what it involves (bribery, theft of assets, distortion of government expenditure, patronage, cronyism) (Morgan 1998:2738; UNDP 1999:7-9; World Bank 1997b:13-15). Other distinctions are made depending on whether the corruption is local or national, personal or institutional, traditional or modern (Morgan 1998). In addition, distinctions are often also made in the literature between economic corruption and political corruption, though the two are necessarily often interlinked. Morgan comments that 'all of these various ways of dividing the concept of corruption into categories offer varying degrees of utility in identifying causes, consequences, and solutions. They suggest that the type of corruption determines the prognosis for solving the problem' (1998:12-13).

An examination of definitions of corruption often leads to discussion as to whether the definitions are universal across all cultural contexts. Morgan asks whether anti-corruption efforts represent a uniform standard of good governance or a misguided effort to impose subjective standards and values on countries and cultures where they are inappropriate (Morgan 1998:13). There is much discussion in the literature about the effects of cultural values and differing legal traditions and customs on whether certain practices are regarded as corruption. Due to these cultural differences, it is often argued that what constitutes corruption may differ between countries. For example, the literature notes that in some countries it may be customary to give a gift as part of a 
transaction, a practice which may often be regarded as bribery in other countries (Larmour 1997; Phongpaichit and Piriyarangsan 1994; Joongi and Jong 1997; UNDP 1999). However, some authors set out a clear distinction between giftgiving and bribery, noting that gifts are ceremonial, of a nominal value and presented in the open, compared to bribes which are secretive and often substantial (Alatas 1990). Larmour notes comments by a Nigerian Head of State, that the gift is usually a token. It is not demanded. The value is usually in the spirit rather than the material worth. It is usually done in the open, and never in secret. Where it is excessive, it becomes an embarrassment and it is returned' (Obasanjo quoted in Larmour 1997:3; UNDP 1999:8). RoseAckerman notes that often the critique of imposition of values is a mischaracterisation of local practices. She comments that many scholars of developing countries 'make it clear that traditions of gift giving do not translate into widespread acceptance of corrupt practices' and that widespread acceptance of corruption is not common (Rose-Ackerman 1999:177). However, issues of cultural relativity remain. Joongi and Jong comment, in the context of bribery as a form of corruption, that to create an international consensus to end the practice of bribery, these cultural differences cannot be disregarded and must be considered. Any efforts against international bribery will remain a contentious issue unless the fears that these cultural differences might be ignored in the process are allayed' (Joongi and Jong 1997:557).

\section{Causes, effects and solutions}

Due to the complexity of the phenomenon of corruption it is hardly surprising that the literature identifies many varied causes of corruption. The World Bank notes that the causes of corruption 'are always contextual, rooted in a country's policies, bureaucratic traditions, political development, and social history' (World Bank 1997b:14). Morgan summarises several widely accepted causes, noting that different methodological approaches identify different causes for corruption (Morgan 1998:13-15). At least three general classes of causes are identified: ethical or cultural causes (such as the changes to religious beliefs and public morality, the conflicts between traditional practices and colonial institutions), economic causes (examining the economic incentives for officials to act corruptly, and economic reasons for the private sector to tolerate, and engage in, corruption), and political causes (examining political systems and institutions, where weaknesses can lead to breakdown of formal rules and systems and lead to greater opportunities for corruption). There is also a growing approach in the literature that recognises that the causes of corruption are complex and interrelated, consisting of factors to do with institutional structures, civil liberties, governance, economic policies, country characteristicsincluding size—and existing inequalities between citizens (Morgan 1998). 
Just as the causes of corruption are complex and varied, so too are the effects. Much of the literature approaches this issue from a political or economic viewpoint, looking at the consequences of corruption on a country's political or economic wellbeing. One of the primary foci in the literature is on the effect of corruption on the economic development of a country. In the past there has been limited empirical data, which has resulted in much theorising about whether corruption was in some circumstances good for the economic development of a country (Morgan 1998; Mauro 1997). However, more recently, emerging empirical studies have begun to show a negative correlation between corruption and long-term sustainable development. In particular, the work of Mauro indicates that corruption can slow development rather than be beneficial (Mauro 1997:83-107; Morgan 1998). Thus, there is increasing consensus on the negative effects of corruption on economic development (Shleifer and Vishny 1993; Morgan 1998).

Commentators point to the similarly negative effect on the strength and legitimacy of political institutions, and the consequences associated with this (Johnston 1997:61-82). For example, some authors note the effects of corruption on electoral processes and outcomes, and the subsequent political practices resulting from this (Etzioni-Halevy 1989:287-304). Nye notes that possible negative effects of corruption on governments include instability, reduction of administrative capacity, loss of legitimacy, waste of government resources and investment distortions (Nye 1989:967-73). The World Bank is also studying the links between good governance and development, especially with regard to anti-corruption (Kaufmann et al. 1997, 1999). One of the most widely discussed consequences of corruption on political and economic wellbeing is the distortion of government expenditure caused by corruption. This often results in public money being spent on large-scale projects - typically military or infrastructure projects-rather than on necessary public services such as health and education. The rationale behind this is that with large-scale expensive projects, more opportunities are presented for corrupt use of the funds (Mauro 1997, 1998; Morgan 1998). Related to this, the literature also notes that corruption exacerbates inequalities and poverty within societies. However, due to limited empirical data, these effects are not explored much beyond general statements (Elliott 1997b; Morgan 1998; UNDP 1999). As Morgan (1998:20) comments, 'additional empirical work to further develop our understanding of this complex issue is imperative. Understanding the full consequences of corruption is an important step in its eradication'.

The solutions to combat corruption suggested in the literature are similarly varied. The strategies used will necessarily be different depending on the type and cause of the corruption. Morgan (1998:20) notes that 'once the types of corruption and its determinants have been identified for a specific situation, 
anti-corruption reform is a two-step process. Policies must be developed that address the fundamental causes of corruption, not just symptoms. Then the political will must be created to implement reforms'. In deciding on ways to combat corruption, there is therefore a recognition that at the heart of the problem of corruption is the issue of good governance (UNDP 1999). RoseAckerman comments that

combating corruption is not an end in itself. The struggle against malfeasance is part of the broader goal or creating a more effective government. Reformers are not just concerned with corruption per se but with its distortionary effect on development and society. Widespread corruption is a sign that something has gone wrong in the relationship between the State and society (1997b:34).

As a result of the focus on the economic and political consequences of corruption, the strategies that are commonly developed to combat corruption also adopt this approach. Morgan (1998:21) sets out the key strategies: 'serious and sincere commitments to counter corruption involve comprehensive institutional or administrative reform, reform of economic policy, legal or judicial reform, and in extreme cases of patronage and cronyism, reform of the political system'. Much of the literature discusses how to prevent officials from engaging in corrupt practices, through methods such as increasing the risks of getting caught, increasing the punishments involved for corruption, and limiting discretion of officials (Rose-Ackerman 1997b:46-55). This is also addressed at the international level with the development of new international agreements containing mechanisms to monitor and combat corruption of foreign public officials in the fields of international commerce and trade (Pieth 1997:119-31).

\section{Corruption as an issue in the international arena}

International action to combat corruption is very recent. Pieth notes that while some unsuccessful efforts began to develop international action on the subject in the 1970s, the topic of corruption has long been regarded as taboo due to its sensitivity (Pieth 1997; Klitgaard 1988). However, there have been several developments among international organisations this decade that have brought the issue of corruption onto the international agenda. One of the first initiatives to combat corruption on an international scale was the OAS Inter-American Convention Against Corruption, which was adopted in Venezuela in 1996. This Convention recognised the negative effects of corruption and the importance of coordinated efforts to combat it, and it has been widely adopted by the members of the OAS. ${ }^{1}$ In addition, in 1997, the OAS adopted the Inter-American Program for Cooperation in the Fight Against Corruption, which sets out guidelines to implement the Convention and to combat corruption, working in four areas: legal, institutional, international, and civil society (OAS website). 
Another important development in the international arena has been the development of the OECD Convention on Combating Bribery of Foreign Public Officials in International Business Transactions. This Convention was signed and adopted by the OECD in December 1997, after several years of negotiation and discussions, and came into force on the 15 February 1999. The Convention has now been signed by all 29 OECD countries as well as five non-OECD countries. Currently, 18 of these have ratified the Convention and the rest are in the process of ratification and implementation of new domestic legislation. ${ }^{2}$ Australia has recently enacted legislation to incorporate the Convention. The Criminal Code Amendment (Bribery of Foreign Public Officials) Act No. 43 of 1999 came into force on 17 December 1999. The Convention represents an important part of the international effort to criminalise bribery in international business deals.

The United Nations has not played a major role in development of international instruments to combat corruption. Early attempts by the UN to address corruption as an international effort were stifled due to the lack of agreement and the atmosphere of distrust that prevailed at the time (Pieth 1997). However, the UN has remained part of the debate and has made efforts in its various forums and bodies to investigate and take steps to combat corruption. In 1996, the UN General Assembly (UNGA) adopted a Declaration Against Corruption and Bribery in International Commercial Transactions (Res.51/191, 16 December 1996). In addition, UNGA also adopted an International Code of Conduct for Public Officials in 1996, which recognised the seriousness of the problems posed by corruption and the importance of international cooperation in action against corruption (Res.51/59, 12 December 1996). Such resolutions are important in signifying broad political agreement in the international community. In 1997, UNGA adopted another resolution, on International Cooperation Against Corruption and Bribery in International Commercial Transactions (Res.52/87, 12 December 1997). George et al. (1999:39) note that it 'is by far the most extensive and significant declaration in support of the criminalization of bribery in international commercial transactions'. The most recent UNGA resolution concerning corruptionAction Against Corruption and Bribery in International Commercial Transactions - reaffirms the previous resolutions on corruption in international commercial transactions, and calls for national and international action against corruption by states (Res.53/176, 15 December 1998). All of these UNGA resolutions were adopted without vote. In addition, several UN programs and projects recognise the importance of addressing corruption as part of their programs. In particular, the UNDP takes an integrated and holistic approach to addressing corruption in its programs (UNDP 1999). 
To date, the World Bank and other international financial institutions have been reluctant to address corruption as an issue. This reluctance is due largely to these institutions' perception of themselves as politically neutral, the limitations of their charters, and because of the sensitivities of many of their member states (UNDP 1999; Pieth 1997). Recently, however, this reluctance has changed, and both the IMF and the World Bank have increased their efforts to develop policies to combat corruption. This is welcome, as these institutions have long been linked with corrupt behaviour associated with their schemes and projects (Pieth 1997; UNDP 1999). The World Bank's approach to corruption is concerned only with the economic causes and effects of corruption. Due to the limits of its legal mandate, the Bank cannot concern itself with 'the exercise of State powers in the broad sense but specifically with the appropriate management of the public sector and the creation of an enabling environment for the private sector' (World Bank 1997b:24). The Bank sees itself as therefore limited to helping to design and implement government programs, by advising on economic policy reform and strengthening institutions, and also providing support in international efforts against corruption (World Bank 1997b). The IMF is also developing policies to combat corruption, one of which denies financial assistance to countries where corruption is likely to undermine economic recovery programs. The IMF has also recently adopted guidelines concerning its role in governance and promoting transparency and accountability in the public sector. The WTO has similarly begun to address corruption, with the establishment of a working group in 1996 focusing on transparency in government procurement (UNDP 1999; George et al. 1999).

Transparency International has had a major influence on increased action in the international arena in the fight against corruption. Transparency International's approach is to build national, regional and global 'coalitions', consisting of involvement of the state, international institutions, civil society and the private sector, to fight national and international corruption. It is founded on the principles of participation, decentralisation, diversity, accountability and transparency. Importantly, Transparency International does not seek to target individual cases of corruption, but rather to focus on building and supporting systems to combat corruption. The influence of Transparency International through its national chapters and its international conferences has been significant, both through increasing public awareness of corruption and through working with other international organisations to develop policies to combat it. Another important contribution of Transparency International has been the development of the Corruption Perceptions Index (CPI) which provides an indication of the levels of corruption believed to exist within countries. More recently, an important development by Transparency 
International is the Bribe Payers Index (BPI) which provides an indication of levels of corrupt practices engaged in by transnational companies abroad.

\section{Empirical data}

As previously noted, one of the principal difficulties in discussing corruption is limited empirical data showing the prevalence and levels of corruption, and the effects that corruption has on countries. While this makes exact 'proof' of the levels and effects of corruption difficult, corruption is nevertheless widely accepted as a common phenomenon. It is recognised that measuring corruption is notoriously difficult owing to the nature of the phenomenon-corrupt behaviour is inherently secretive, which makes gathering empirical evidence difficult, if not impossible. Despite these difficulties, however, increasing numbers of empirical studies are emerging that attempt to measure levels and effects of corruption (Elliott 1997b:241-44).

Perhaps the most widely referred to is the Transparency International CPI, an annual report of Transparency International, which, in 1999, ranked 99 countries according to the perceived levels of corruption in the country (www.transparency.org). The CPI has been described as a 'poll of polls' and draws upon a large number of independent organisations' surveys of expert and general public views of the extent of corruption in many countries around the world. A number of countries are not included, however, due to insufficient availability of reliable data, and Transparency International stresses that it is an index of perceptions of corruption rather than a direct measurement of precise data. Importantly, Transparency International notes that the CPI shows that 'corruption is by no means perceived to be a plague confined to the developing countries. Numerous countries in transition in Central and Eastern Europe have very low rankings, while a number of leading industrial countries have scores that highlight the serious corruption problems that they must address' (www.transparency.org). The CPI is useful because it broadens the awareness of corruption, stimulates anti-corruption reform and influences the policies of international organisations, aid agencies and multinational corporations.

In addition to the CPI, Transparency International recently released a new index, the BPI. This index provides a ranking of 19 leading exporting countries in terms of the degree to which their corporations are perceived to be paying bribes abroad in order to win business opportunities. The BPI involved a survey in 14 leading emerging market economies. ${ }^{3}$ The survey involved questioning senior executives at major companies, chartered accountancies, chambers of commerce, major commercial banks and law firms in each of the 14 emerging market economies about their perceptions of the levels of bribes being offered to their countries by corporations from abroad (www.transparency.org). The BPI is significant in that it attempts to show the responsibility and the role that 
industrial countries play in international anti-corruption efforts. Transparency International comments that 'the CPI only points the finger at the recipients of bribery. TI has always felt that this was inadequate, particularly since it does not reflect the responsibility of exporting countries for international corruption. The 1999 BPI is the first attempt to address this' (www.transparency.org). The BPI highlights the responsibility of industrial countries to take action to stop transnational corporations in their countries from engaging in corrupt behaviour abroad. The BPI is therefore a monitor of the effectiveness of the implementation of the OECD Anti-Bribery Convention.

\section{Why combat corruption?}

There has been some disagreement about the importance of combating corruption. Some authors have claimed that corruption may in some cases be desirable, facilitating and benefiting the development of a country (Morgan 1998). This view considers that corruption improves the efficiency of the country by providing a way around unnecessary, cumbersome regulations and bureaucratic delays. It is also seen as beneficial as it supplements the incomes of officials who may otherwise be poorly paid. This sort of view, however, is becoming less prevalent, as emerging empirical studies suggest that there is a negative correlation between corruption and the development of a country (Morgan 1998). The World Bank comments that such arguments are focused on the short term and therefore fail to take into account any objective other than enhanced efficiency in the short term. There are not only direct costs of corruption-diversion of money - but also indirect negative consequences, costly in the long term (Morgan 1998). The World Bank notes that in the long run, 'the results are likely to be costly in terms of economic efficiency, political legitimacy, and basic fairness' (World Bank 1997b:15). Such arguments also fail to address the underlying issue of what causes corrupt practices in the first place- the essential underlying structural inequalities and distortions within society that lead to corruption (Ward 1989).

Hence, there appears to be more of a consensus on the need to develop policies and measures to combat corruption, both in the literature, and also increasingly in practice at the national and international levels. While debates continue at the academic level about the definitions of corruption and on aspects of cultural relativity, it seems clear that corruption is a hindrance to the development and prosperity of a country. 'Governments can no longer deny its pernicious effects. Debunking this myth has been a crucial first step for building political will for any anti-corruption policy' (Morgan 1998:25; Shleifer and Vishny 1993:600). There is much discussion in the literature as to the possible benefits of eliminating corruption in countries, and these differ in emphasis depending on the discipline from which they come. On a general 
level, much of the literature focuses on the possibilities for increased development of countries. There is also focus on the opportunities for countries — and for the poor especially—arising from escaping the distortions of government expenditure on public services and infrastructure that are created by corruption. Those involved in business and trade anticipate benefits from the efficiencies of a corruption-free system, such as increased certainty in business transactions and increased opportunities for investment (Joongi and Jong 1997).

Possibly one of the most important reasons for combating corruption is the fundamental change in government that is required in some cases. Corruption is often associated with a lack of good governance: unrepresentative, autocratic, unstable and illegitimate regimes (Gould 1991; UNDP 1999). Corruption is often seen as essentially resulting from a bad system, rather than solely due to the influence of corrupt people in the system (Klitgaard 1988; Gould 1991). As Euben notes '... corruption is a disease of the body politic. It has less to do with individual malfeasance than with systematic and systemic degeneration of those practices and commitments that provide the terms of collective self-understanding and shared purpose' (1989:222-3). Much of the focus of the literature is on fighting corruption to improve good governance. Raising the standards of governance is thought to lead to many benefits for countries, especially in terms of economic, political and social development (UNDP 1999). It is seen as necessary for recognition of fundamental human rights, the rule of law, strengthening of institutions, political participation and strengthening of civil society and democracy (Ruzindana 1997; UNDP 1999). Much emphasis is also placed on the importance of strong leadership in efforts to combat corruption and promote good governance (Ruzindana 1997). Fighting corruption and promoting good governance is therefore crucial to developing an environment that facilitates the social, political and economic development of people within a country.

\section{The inadequacies of current approaches}

As previously noted, while corruption has been present in various forms in societies worldwide for thousands of years, it is only recently that coordinated efforts have begun at the international level to address the issue, and to discuss causes, effects and possible international solutions to the problem. Previously, the discussion of corruption as an international issue, both in the literature and in the international political arena, was negligible. It seems to have been regarded as a taboo matter (Pieth 1997). Until the mid 1970s, any analysis of corruption had a national focus (LeVine 1989). This appears to have been largely due to corruption being viewed as a domestic political issue which was the responsibility of individual states to address (LeVine 1989:686; Perry, 
1997:36). Linked with the approach of regarding corruption as a national issue, there continue to be arguments that regard such international action as an unacceptable imposition of 'Western' values and customs on countries (RoseAckerman 1999; Pieth 1997). This continues to create tensions between developed and developing countries. As a result, Myrdal (1989:406) notes that the result is a certain 'general bias that we have characterized as diplomacy in research. Embarrassing questions are avoided by ignoring the problems of attitudes and institutions...The taboo on research on corruption is, indeed, one of the most flagrant examples of this general bias'.

This 'diplomacy in research', in addition to the general diplomatic approach on the international political level of non-interference with other state's domestic policies on corruption, has meant that the issue of corruption as an international problem was slow to be addressed. However, the enactment in 1977 of the US Foreign Corrupt Practices Act, and the subsequent attempts by the United States to get corruption on the international agenda marked the beginnings of an international movement to combat corruption. This 'opened a Pandora's box which much of the world - particularly those countries most affected by the revelations - would have preferred to have remained closed. On the other hand, the new transnational corruption, once revealed, had to be recognized for what it was-a new and dangerous challenge to the stability and predicability of the international market' (LeVine 1989:687). Increasingly, the focus turns to the responsibility and role of states in combating corruption, both internally and externally, for it is the efforts of states on the national and international level that are crucial in the elimination of corruption.

However, the examination of anti-corruption efforts by states remains limited, and to some extent a 'diplomacy in research' still exists. The current literature and action in the international domain approaches the causes, effects and solutions to corruption from largely an economic or political viewpoint. To some extent this reflects international practice in general, where consensus and action is more common and more readily arrived at in economic areas. In addition, much of the corruption literature and international action focuses on the actions of government officials only, and how to make these actors more accountable. For example, the OECD Convention focuses on combating bribery of foreign public officials in international business conventions; the four UNGA instruments concern adoption of an international code of conduct for public officials, and resolutions and a declaration concerning action and cooperation against corruption and bribery in international commercial transactions; and the World Bank's mandate is restricted to the economic causes and effects of corruption. Focusing solely on the actions of public officials often obscures the underlying wider responsibility of states to provide an environment in which corruption is 
not tolerated or condoned. The role of the state therefore seems marginalised, and the analysis restricted to economic concerns.

These approaches and strategies towards combating corruption are entirely valid and certainly necessary. The above comments are not intended to imply criticism of the usefulness of this approach per se. However, it is proposed here that this approach alone is inadequate. There is insufficient examination in the literature of the responsibility and role of the state to prevent corruption, both directly - by not engaging in corrupt behaviour through its officialsand indirectly - by not condoning an environment that tolerates or encourages corrupt behaviour by others. While current approaches address corrupt behaviour of officials and how to prevent and punish this sort of corruption, it is also important to address the corruption of the system as a whole that tolerates or condones corrupt behaviour, and to analyse the role and responsibilities of the dominant actor in this system, the state.

While general statements are often made about the effect of corruption on poverty and development, there is no explicit recognition that corruption is more than just wealth misappropriation or abuse of power. The effect of corruption on people's rights and needs has largely been left out of the corruption debate. There is little direct reference to human rights in the Preamble to the OECD Bribery Convention ('Considering that bribery... raises serious moral and political concerns, undermines good governance and economic development, and distorts international competitive conditions'); little in the Preamble to UNGA Resolution 51/59 of 1996 adopting a code of conduct for public officials ('Concerned at the seriousness of problems posed by corruption, which may endanger the stability and security of societies, undermine the values of democracy and morality and jeopardize social, economic, and political development'); and no mention in the Preamble to UNGA Declaration against Corruption and Bribery in International Commercial Transactions 51/191 of 1996 . There is little reference to human rights concerns in the Preamble to the UNGA Resolution on International Cooperation Against Corruption and Bribery in International Commercial Transactions 52/87 of 1997 ('Convinced that such practices undermine the integrity of State bureaucracies and weaken social and economic policies by promoting corruption in the public sector, thus diminishing its credibility'); and only some mention in the UNGA Resolution on Action Against Corruption and Bribery in International Commercial Transactions 53/176 of 1998 ('Concerned at the seriousness of problems posed by corruption, which may endanger the stability and security of societies, undermine the values of democracy and morality and jeopardize social, economic, and political development').

The preamble to the OAS Inter-American Convention Against Corruption does make reference to the conviction that 'corruption undermines the 
legitimacy of public institutions and strikes at society, moral order and justice, as well as at the comprehensive development of peoples', and of 'the need to strengthen participation by civil society in preventing and fighting corruption'. The UNDP has also recently begun to consider the effect of corruption on governance. Overall, however, there is little reference to human rights in the corruption literature and in international action and instruments against corruption. Given the importance of human rights discourse in international law, an examination of corruption from a human rights perspective may shed some new light on the corruption debate, and provide some impetus for the way forward in anti-corruption efforts.

\section{An alternative approach}

\section{A human rights approach}

The growth of human rights discourse in international relations over the last 50 years has been impressive and is now universally recognised as a prominent aspect of international law. While there remain disagreements on aspects of the human rights jurisprudence, there is no longer debate on whether it is a legitimate subject for discussion between states (DFAT 1998). The basis of international human rights law rests upon the International Bill of Rights as the cornerstone of the human rights system, comprising the Universal Declaration of Human Rights (UDHR), the International Covenant on Civil and Political Rights (ICCPR) and the International Covenant on Economic, Social and Cultural Rights (ICESCR). These three instruments contain the fundamental rights and freedoms that are recognised as being universal in nature and essential to the enjoyment of life by all people. The two Covenants, which are binding on states that ratify them, have been widely accepted by the international community. One of the most important results of the development of the notion of universally applicable international human rights standards has been the recognition that human rights are a legitimate international concern.

Since the development of the UDHR, human rights have been regarded as inherent (that is, applying as a result of a person's humanity, rather than bestowed), inalienable (that is, cannot be taken or given away), and universal (that is, applying equally to all persons, regardless of race, nationality, status, sex, religious beliefs, and so on) (UDHR; DFAT 1998). There has been much discussion in the literature as to the relationship between the rights contained in the ICCPR and the ICESCR. Much has been made of the categorisation of the rights contained in the Covenants, and whether there is a hierarchy of rights. However, there is an increasing body of jurisprudence that takes a broad approach to human rights and argues against the categorisation of rights. This 
approach argues that the rights contained in the two Covenants are indivisible, interrelated and interdependent. The Vienna Declaration and Program of Action that were adopted at the Vienna World Conference of Human Rights in 1993 supports this approach and it is the approach endorsed by many countries, including Australia (DFAT 1998). This approach recognises that the values contained in the Covenants cannot be protected in isolation from each other, but that a more holistic approach should be taken in recognition of the interdependent nature of these rights and in the pursuance of the goal of human rights discourse - that of the pursuit of human dignity. Scott comments that

[a] general conceptual analysis of human rights... should be approached with sustained attention to the underlying humanity of human rights and to the reality that human experience rarely confines itself to neat categories, much less highly abstract ones... By breaking out of overly rigid categories, human rights analysis can better focus on the underlying interests that rights should serve to protect... and the kinds of harm, practices, and systems that have historically generated the need for a discourse on human rights (1999:636-7).

The approach that is taken in this chapter is to transcend the categorisation of rights under the two Covenants, and to group the rights contained in those Covenants into categories that concentrate on people's inherent needs. There is no intention of suggesting that these groupings are in any way rigid, as the rights contained in the Covenants may be categorised in any number of ways. It simply represents an attempt to break from the rigid dichotomy drawn between the ICCPR and the ICESCR. This is useful for the purposes of this chapter, which explores human rights aspects of the complex phenomenon of corruption. The groupings serve as a productive way to examine how the fundamental needs of people are affected by corruption, and therefore how their rights are affected also. The groupings of rights used in this chapter are as follows

1. Rights to affiliation

- right to self-determination

- right to freedom of association

- right to freedom of cultural belief and practice

- right to freedom of religion

2. Rights to life, bodily health and integrity

- right to freedom from torture

- right to life, liberty, security of person

- right to an adequate standard of living

- right to health and wellbeing

3. Rights to political participation

- right to freedom of expression

- right to vote 
4. Rights to non-discrimination and the rule of law

- right to a fair trial and recognition as an equal person before the law

5. Rights to social and economic development

- right to just and favourable conditions of work

- right to education.

Examining a topic through a human rights lens involves focusing on the effects that a policy or practice has on the fundamental rights of people. It involves recognition that people have inherent rights, the protection of which must have consideration in states' policies and practices. It also involves examination of these policies and practices to determine their effectiveness or otherwise in protecting human rights. Therefore, this involves attention to the role and responsibilities of states in the creation of an environment that is conducive to the protection of human rights. Ultimately, for the successful prevention and elimination of corruption, it is necessary for the system as a whole to be involved. Transparency International notes that this must mean 'the involvement of all the stakeholders which include the State, civil society and the private sector' (Transparency International website). Moving from an economic and political perspective on corruption to a human rights approach involves shifting from viewing corruption as being a misappropriation of wealth and distortion of expenditure (that is bad for the economic and political stability of a country), to viewing corruption and the tolerance of corruption by states as also being a breach of fundamental human rights (due to the deleterious effects corruption has on people and on the state's ability to enforce these rights). Using the discourse of human rights enables the effects that corruption has on the ordinary person-especially in his/her contact with the state- to be recognised. Too often, the sufferings of people as a result of corrupt practices are hidden behind vague euphemistic statements of development and poverty levels that fail to draw national or international attention and stimulate the necessary action. It is proposed here that, by examining the human rights cost of corruption, added weight is given to anti-corruption efforts, as well as to human rights protection. A human rights approach to corruption provides an existing international procedural framework on which to base action against corruption to achieve minimum standards of protection of rights (HRCA 1995).

This chapter examines whether the generally recognised causes of corruption and the effects on people can be regarded as breaches of fundamental human rights, as grouped loosely into the categories broadly representative of necessary human needs. The issues that arise from recognising the role of states in tolerating corruption, both on the national and international levels, and the responsibility of states towards developing effective national and international mechanisms to combat corrupt behaviour are also important. Despite the 
limitations of the empirical data, there is an understanding that the phenomenon of corruption is widely recognised as prevalent, as is the usefulness of anecdotal evidence in this regard.

\section{The Human Rights Covenants}

While the rights noted above are grouped into categories in an attempt to use broad groupings based on the needs of people, it is recognised that the rights are drawn from two distinct Covenants. These Covenants place different obligations on states as to the realisation of the rights contained in the Covenants. The ICCPR provides that the state must respect and ensure the rights of individuals immediately; the ICESCR, by contrast, provides that the state must 'take steps...to the maximum of its available resources, with a view to achieving progressively the full realization of the rights' (Article 2 of both Covenants). However, there is increasing consensus in the literature and in the international arena-including the Committee on Economic, Social and Cultural Rights (CESCR) - that this difference in obligations does not indicate that states are free to delay the implementation of respect for the rights contained in the ICESCR. Rather, states must work towards the implementation of the rights, beginning with satisfying minimum standards (Yamin and Maine 1999:586-91). In addition, both the 1986 Limburg Principles on the Implementation of the International Covenant on Economic, Social and Cultural Rights (Limburg Principles) and the 1997 Maastricht Guidelines for Violations of Economic, Social and Cultural Rights (Maastricht Guidelines) indicate that states are required to move towards the full implementation of economic, social and cultural rights as soon as possible, and that the differing obligations contained in the ICESCR do not imply that states can defer efforts towards realisation of these rights.

What constitutes violation of the Covenants? Both the Limburg Principles and the Maastricht Guidelines provide guidance as to the nature and scope of the obligations contained within the ICESCR and also provide examples of what constitutes a violation of the Covenant. Both sets of guidelines were developed by a group of distinguished experts in international law, at meetings convened by the International Commission of Jurists (Geneva), the Urban Morgan Institute for Human Rights (Ohio, USA), and the Centre for Human Rights, Faculty of Law at Maastricht University (the Netherlands). Participants were a diverse range of experts from many countries, including academics, representatives of centres for human rights, non-governmental organisations, the International Commission of Jurists, staff members of the UN, and its Specialised Agencies and Committees. ${ }^{4}$ The Limburg Principles have subsequently been adopted as an official UN document. ${ }^{5}$ Both the Limburg Principles and the Maastricht Guidelines have been adopted widely as 
interpretive of the obligations in the ICESCR, and are useful for determining 'the general contours of possible violations of these rights' (Leckie 1998:89).

While both the Limburg Principles and the Maastricht Guidelines refer to rights in the ICESCR, they also accept the indivisibility and interdependence of the rights contained in both the ICESCR and the ICCPR. They also note that consideration must be given to the implementation and protection of all the rights contained in these Covenants, that a failure by a state to comply with an obligation in either Covenant is a violation under international law of that treaty, and that states are as responsible for violations of economic, social and cultural rights as they are for violations of civil and political rights. Therefore the guidelines provided in these documents are useful indicators of the kinds of behaviour by states regarded as a violation of either Covenant, and serve as guidelines for interpretation in addition to the relative clarity of provisions in the ICCPR as to violations of these rights. The Maastricht Guidelines are developed from the Limburg Principles and build on them, specifically providing guidelines as to the nature and scope of violations of economic, social and cultural rights. They are therefore a useful place to start when considering what amounts to a violation of a provision of the Covenants (Box 3.1).

The principles set up by the Maastricht Guidelines provide useful indicators as to what constitutes violations of rights in the ICESCR. Previously, there was some difficulty in determining what amounted to a violation as few standards of appropriate conditions were clearly set out, and this was compounded by the discussion as to what 'progressive realisation' meant. This was in contrast to the relative clarity of the rights and standards in the ICCPR, which was often backed up by indicators, bodies of national jurisprudence and precedent to draw upon as to what constituted appropriate conditions (Yamin and Maine 1999). As a result, these Guidelines may make things a little clearer concerning the responsibilities of states to protect rights, and states' culpability in certain circumstances of rights violations. Sometimes, due to the limited empirical evidence, it is difficult to establish a direct causal relationship between a state's actions or omissions and breaches of human rights. An example of this is in the case of corruption, where there is often a lack of evidence to establish a direct causal relationship with human rights breaches due to the secretive nature of corruption. These guidelines, however, indicate that states have responsibility both through action, and through countering inaction on the part of themselves and their agents, to provide an environment where human rights are respected, protected and fulfilled, and achieve a certain internationally-agreed standard. 


\section{Box 3.1 Maastricht Guidelines on violations of economic, social and cultural rights}

II. The meaning of violations of economic, social and cultural rights...

14. Violations can occur through the direct action of States or other entities insufficiently regulated by states. Examples of such violations include

(a) The formal removal or suspension of legislation necessary for the continued enjoyment of an economic, social and cultural right that is currently enjoyed

(b) The active denial of such rights to particular individuals or groups, whether through legislated or enforced discrimination

(c) The active support for measures adopted by third parties which are inconsistent with economic, social and cultural rights

(d) The adoption of legislation or policies which are manifestly incompatible with pre-existing legal obligations relating to these rights, unless it is done with the purpose and effect of increasing equality and improving the realisation of economic, social and cultural rights for the most vulnerable groups

(e) The adoption of any deliberately retrogressive measure that reduces the extent to which any such right is guaranteed

(f) The calculated obstruction of, or halt to, the progressive realization of a right protected by the Covenant, unless the State is acting within a limitation permitted by the Covenant or it does so due to a lack of available resources or force majeure

(g) The reduction or diversion of specific public expenditure, when such reduction or diversion results in the non-enjoyment of such rights and is not accompanied by adequate measures to ensure minimum subsistence rights for everyone.

15. Violations can also occur through the omission or failure of States to take necessary measures stemming from legal obligations. Examples of such violations include

(a) The failure to take appropriate steps as required under the Covenant

(b) The failure to reform or repeal legislation which is manifestly inconsistent with an obligation of the Covenant

(c) The failure to enforce legislation or put into effect policies designed to implement provisions of the Covenant

(d) The failure to regulate activities of individuals or groups so as to prevent them from violating economic, social and cuitural rights

(e) The failure to utilise the maximum of available resources towards the full realisation of the Covenant

(f) The failure to monitor the realization of economic, social and cultural rights, including the development and application of criteria and indicators for assessing compliance

(g) The failure to remove promptly obstacles which it is under a duty to remove to permit the immediate fulfilment of a right guaranteed by the Covenant

(h) The failure to implement without delay a right which it is required by the Covenant to provide immediately

(i) The failure to meet a generally accepted international minimum standard of achievement, which is within its powers to meet

(j) The failure of a State to take into account its international legal obligations in the field of economic, social and cultural rights when entering into bilateral or multilateral agreements with other States, international organisations or multinational corporations.

Note: The Limburg Principles and the Maastricht Guidelines set out examples of what amounts to violations. The failure of a state to comply with an obligation under either Covenant is a violation of the international obligations under that Covenant. Essentially, states have obligations to respect, protect and fulfil the rights contained in the Covenants. The Maastricht Guidelines provide some guidance as to what these obligations mean: the obligation to respect requires states to refrain from interfering with the enjoyment of the rights; the obligation to protect requires states to prevent violations of rights by third parties; the obligation to fulfil requires that states take appropriate legislative, administrative, budgetary, judicial and other measures necessary towards the full realisation of rights. The Maastricht Guidelines also note that there are then obligations on the state of conduct and result; the obligation of conduct meaning that the state must engage in conduct designed to realise the enjoyment of rights; and the obligation of result meaning that there is a requirement on the state to achieve a certain minimum standard of respect for rights as agreed in the international arena.

Source: International Commission of Jurists, 1998. 'Maastricht Guidelines on Violations of Economic, Social and Cultural Rights', Human Rights Quarterly, 20(3):695-97. 


\section{Classical notions of corruption and a human rights approach}

An examination of corruption in terms of the effects that it has on human rights involves highlighting specific rights and how they may be violated. Sometimes there may be difficulties in this, as specific human rights are often bound up in broad concepts. For example, there is some discussion in the literature linking corruption and ideas of development, including aid, and also corruption and ideas of democracy. Currently, however, these analyses tend to focus on the economic and political costs to development and political stability, rather than examining to any great extent the human costs (Morgan 1998:15-20). As Alston points out, it is necessary to break down these broad terms such as 'development' and 'democracy' and to identify the values and rights contained within them in order to promote recognition of these rights. Alston goes on to note: '[w]e should affirm not that there should be 'democracy' and 'development', but that a range of quite specific values must be promoted and that those values, taken as a whole, will enable the realization of metanorms of democracy and development' (HRCA 1995).

However, a human rights approach to corruption should also involve consideration of the broader, more systemic effects that corruption has on society as a whole. Examining corruption in terms of human rights highlights the obligations and accountability of states to facilitate the creation and the maintenance of a society in which human rights are respected and human dignity is promoted. To some extent this involves an analysis of existing discourses of the elements that are thought to be important for the idea of a good society, and the effect of corruption on these elements. It involves examination of ideas of democracy, development, the rule of law, accountability of power, and so on. While this involves looking at specific values, such as that proposed by Alston, it is also important to consider broad values that may be seen to be inherent in ideas of what a good society consists of, such as expectations of fairness, transparency, honesty and trustworthiness from those in a position of power within states. A corrupt state may be highlighted by discrepancies between what the state claims to do, and what actually happens, which in turn leads to distrust and cynicism by the people. Corruption may also lead to these legitimate expectations of society being violated as a result of lower standards that the state is prepared to enforce, including human rights standards. The lowering of standards in addition to general disillusion with corrupt practices in government may result in changes to society's attitudes and expectations, as reluctant acceptance of lower standards develops at a societal level. Therefore, an examination of the role of the state and society in considering the causes, consequences and methods of combating corruption is important. This recognition that corruption may be part of a broader societal problem rather than an individual economic one may be important for the success of 
anti-corruption efforts, and in particular for efforts to ensure protection for human rights against corruption.

The view that corruption is not simply an economic issue, but one that has broader societal origins and implications is an historical one. Heidenheimer et al. (1989:5) note that in ancient times, political theorists such as Aristotle regarded corruption as being primarily a moral issue, where corruption was used in an analysis of the structures and functions of society to characterise situations which were perceived to be 'marked by the decay of the moral and political order'. Aristotle's view of corruption involved looking at the ideals of a particular regime or political system; where the system fell short of these ideals, it was regarded as corrupt (Euben 1989). Euben notes that Aristotle's ideas of a healthy political system involved ideals of administration of justice, non-materialism in economic matters, diversity and unity, equality, higher guiding values of public interest over private values, and notions of citizenship (Euben 1989:227-30). Where these values were compromised, the system was viewed as corrupt. Corruption was viewed as 'a disease of the body politic', a degeneration and disintegration of the political system (Euben 1989:222; Friedrich 1989:18). Friedrich comments that corruption was therefore regarded as being a disintegration of the belief system upon which a particular political system rests' (1989:17). This view of corruption is therefore much broader than simply viewing corruption as an economic issue involving individual impropriety. Friedrich notes that this broader historic notion of corruption has developed into the modern sense of corruption-the abuse of public power for private gain. 'Corruption, then, has become a particular form of political pathology rather than a global degeneration' (Friedrich 1989:21). The current economic focus of corruption has possibly become more prominent due to the increased importance of economic activities in society and in international discourse, and also due to the increased notions of individuality in society. However, it is proposed that a reversion to these classical notions of corruption as being a broader societal problem may be useful for an alternative approach to anti-corruption efforts.

\section{Corruption and violations of human rights}

The difficulties encountered in answering the question as to whether corruption can lead to human rights violations may well be one of the reasons why it has not been adequately addressed in the past. Indeed, due to the limited empirical evidence establishing a link between corruption and breaches of human rights, it is difficult to present a clear case. This is not due to the absence of information regarding the status of human rights within a country, as this is fairly readily available, often in the form of UN reports, particularly annual reports such as the UNDP Human Development Report. The difficulty lies in linking breaches 
of these rights with incidences of corruption. This is the crucial work that remains to be done. There is some anecdotal evidence in the literature which can be drawn upon to demonstrate how corruption can run counter to states' obligations to respect, protect, and fulfil human rights, therefore leading to breaches. While these data are far from perfect, they nevertheless provide examples of how corrupt behaviour can lead to human rights violations and, therefore, provide a starting point for discussion.

Rights to affiliation. This category is proposed to include the right to selfdetermination (ICCPR, Article 1; ICESCR, Article 1), the right to freedom of association (ICCPR, Article 22; ICESCR, Article 8), the right to freedom of cultural belief and practice (ICCPR, Article 27; ICESCR, Article 15), and the right to freedom of religion (ICCPR, Article 18). An example of a possible violation of these rights, based on case law and recent reported events, is of corrupt behaviour on the part of a government official regarding leasing territory to private companies for mining or forestry. Where there is a group of indigenous people living and subsisting within the territory, extensive logging or mining may lead to the violation of the right of the group not to be deprived of their means of subsistence, a part of the right to self-determination under both Covenants (Jayawickrama 1998; Cockcroft 1998). In addition, this could also be construed as a violation of the right of the group to freedom of their cultural beliefs and practices guaranteed under both Covenants, if the change in the environment so drastically alters their way of life. Larmour points to several examples reported in two South Pacific countries where government officials were engaging in corruption in relation to the timber industry, to the detriment of traditional communities (Larmour 1997:6-8). Rose-Ackerman also notes the deleterious effects of widespread inefficient and environmentally destructive practices on traditional communities, many of the causes of which can be linked with corrupt practices in allocation and exploitation of natural resources (Rose-Ackerman 1999:19, 33). For example, corruption is often associated with decisions to undertake development projects, such as large-scale dams, which invariably cause the displacement of people from traditional lands, with violations of rights, including the right to self-determination and to a means of subsistence (HRCA 1995; Alatas 1999:94). As many as 90 million people may have lost their homes to make way for dams, roads and other development projects over the course of the last decade (Brown 1997:124).

Rights to life, bodily health and integrity. The general category of rights to life, bodily health and integrity is proposed to include the right to freedom from torture (ICCPR, Article 7), the right to life (ICCPR, Article 6), liberty (ICCPR, Articles 9-13), security of person (ICCPR, Article 9), the right to an adequate standard of living (ICESCR, Article 11), and the right to health and wellbeing (ICESCR, Article 12). One example of a violation of these rights is 
corrupt officials allowing the dumping of toxic waste into an area which is planned for residential purposes. There are also instances documented where the payment of bribes is thought to have influenced public officials' decisions in a Southeast Asian nation to allow the illegal importation of toxic waste from other countries (BAN website). Resulting ill health of the community caused by exposure to the toxic waste may mean that human rights-particularly the right to life, and the right to health and wellbeing-may be violated (Jayawickrama 1998).

Violations of the right to health and wellbeing are also linked with corruption through the distortion of government expenditure by corrupt officials. One study sets out preliminary findings that corruption reduces government spending on health, as a result of money going to large-scale projects, where the misuse of funds is easier to hide and presents more opportunities for corruption (Mauro 1998:265). It would be generally accepted that reduced spending on health is likely to lead to a decrease in the quality of healthcare available, and therefore a violation of people's right to health and wellbeing. It is also suggested that this can lead to corrupt behaviour on the part of medical professionals who must be bribed in order to obtain healthcare, further violating these rights (Alatas 1999; Cockcroft 1998).

High levels of corruption in governments and the resulting violations of human rights - especially the right to freedom from torture, right to life, liberty, and security of person-have often been linked. The Human Rights Committee- the UN treaty committee monitoring the ICCPR - has implied several times in its Annual Reports recognition of a link between corruption and violations of the right to life and the right to freedom from torture. In its 1998 Report, it noted in relation to one West Asian country

The Committee is deeply concerned that all government power...is concentrated in the hands of an executive which is not subject to scrutiny or accountability, either politically or otherwise...the Committee notes with grave concern reports from many sources concerning the high incidence of summary executions, arbitrary arrests and detention, torture and illtreatment by members of security and military forces, disappearance of many named individuals and of thousands of people....and forced relocations. In this respect, the Committee expresses its regret at the lack of transparency on the part of the Government in responding to these concerns (Human Rights Committee Report A/53/40 1998, paras 96-7).

Rights to political participation. This category is proposed to include the right to freedom of expression (ICCPR, Article 19) and the right to vote (ICCPR, Article 25). Freedom of expression includes the freedom to seek, receive and impart information and ideas of any kind. Violations of this right can occur on all three fronts as a result of corruption. Freedom of the press is 
essential to promote government accountability and transparency and there are several ways in which a corrupt government can stifle this freedom and control the media, which therefore may violate the right of freedom of expression (Rose-Ackerman 1999:165-7). Rose-Ackerman also notes the negative effect on freedom of expression by strong libel laws protective of public officials, pointing out that several North American, European, Middle Eastern, Asian and Latin American states have laws protecting public officials. These sorts of provisions often prevent or delay the publishing of matters that are of public interest - of which corruption by public official is certainly one-which may lead to a violation of the right to freedom of expression (Rose-Ackerman 1999:166-7). The CESCR noted in its 1998 Annual Report, in relation to the situation in one Middle Eastern state that 'the ability of people to defend their economic, social and cultural rights depends significantly on the availability of public information. Efforts to ensure accountability and to combat corruption also require such information in order to be effective' (CESCR Report on the $16^{\text {th }}$ and $17^{\text {th }}$ Sessions E/1998/ 22, para 346).

The Human Rights Committee noted in 1995, in relation to a North African state

The Committee is...concerned that present laws are overly protective of government officials, particularly those concerned with security matters, it is particularly concerned that those government officials who have been found guilty of wrongdoing remain anonymous to the general public, becoming immune from effective scrutiny (Human Rights Committee Annual Report A/50/40, Vol.I, 1995, para 86).

And again in relation to the same state

The Committee is concerned that dissent and criticism of the Government are not fully tolerated.... and that, as a result, a number of fundamental freedoms guaranteed by the Covenant are not fully enjoyed in practice. In particular, it regrets the ban on the publication of certain foreign newspapers. The Committee is concerned that those sections of the Press Code dealing with defamation, insult and false information unduly limit the exercise of freedom of opinion and expression as provided for under article 19 of the Covenant. In this connection, the Committee is concerned that those offences carry particularly severe penalties when criticism is directed against official bodies as well as the army or the administration, a situation which inevitably results in self-censorship by the media when reporting on public affairs (Human Rights Committee Annual Report A/50/40Vol.I, 1995, para 89).

The right to vote and to be elected at genuine periodic elections-an aspect of the right to participation in public affairs-consists of two elements: the requirement of universal and equal suffrage and secrecy of ballot, and 
the guarantee that the vote must reflect the free expression of the will of the electors. This right can be violated by corrupt behaviour on the part of public officials, which is designed to interfere with the integrity of the electoral process, either through the bribery of electors to induce them to vote or to refrain from voting, or through the bribery of election officials to induce them to interfere more directly with the electoral process (Jayawickrama 1998). Such corrupt behaviour has occurred in some North American, European and Asian states (Rose-Ackerman 1999:137-8). Not only does corruption affect the voting process, but also the campaigning; politicians' political campaigns are often funded by wealthy interests concerned with influencing legislative outcomes and government policy. Examples of this occur in some North American, European and Asian states (Rose-Ackerman 1999:132-5). This represents further interference in the integrity of the electoral process and a possible violation of rights to vote and participate in public affairs.

Rights to non-discrimination and the rule of law. This category includes the rights to a fair trial and recognition as an equal person before the law (ICCPR, Articles 9-15). The main violation of these rights discussed in the literature is the right to a fair and public hearing by a competent, independent and impartial tribunal established by law. Corruption can affect the judicial process in several ways so that rights to a fair trial are violated.

A corrupt or politically dependent judiciary can facilitate high-level corruption, undermine reforms, and override legal norms. When the judiciary is part of the corrupt system, the wealthy and the corrupt operate with impunity, confident that a well-placed payoff will deal with any legal problems (Rose-Ackerman 1999:151).

If one party has engaged in bribery of a judge, court official, or through bribery has access to documents the other party does not, then the trial will hardly be impartial, independent or fair (Jayawickrama 1998). In addition, where corruption of the entire government system is prevalent, the judiciary may not be impartial towards the state, so an individual attempting to take action against the state may not receive a fair trial. Rose-Ackerman notes that this has been the case in some Latin American and Asian countries, due to the lack of constraint by the judiciary of the executive (Rose-Ackerman 1999:147-8). For this reason, even where the judiciary is independent and impartial, it is necessary to conduct deeper reforms of the political system where corruption is prevalent in the state (Rose-Ackerman 1999). However, an honest, independent judiciary can be helpful in reforming the system and in protecting human rights, as has previously been the case in some European, Latin American and Asian states (Rose-Ackerman 1999:151-2). The CESCR has noted the importance 


\section{of judicial independence in protection of human rights, commenting with concern in 1997 in relation to a Caribbean country}

that, according to the information received from various sources, that there is no mechanism for lodging complaints against the arbitrariness or corruption of some judges and that there is no appellate procedure for challenging the discriminatory application of the law, an executive degree or a decree of a court (CESCR Annual Report on the $14^{\text {th }}$ and $15^{\text {th }}$ Sessions E/1997/22, para 227).

The following year, however, the Committee noted with appreciation in relation to the same country that

the measures taken to combat the problem of corruption of public officials, including judges, and in particular the increase in the salaries of government officials and judges. Furthermore, the Committee notes that the procedure for nominating judges to the new Supreme Court has been made public and transparent, with the objective of guaranteeing the impartiality of the judiciary and its independence from the executive... The Committee recommends that measures to combat the arbitrariness and corruption of some judges and public officials be pursued. In particular, the Committee recommends that information on the means available, if any, to challenge the discriminatory, arbitrary and unjust application of a law, an executive decree or a court decree be provided in the State party's next periodic report (CESCR Annual Report on the $16^{\text {th }}$ and $17^{\text {th }}$ Sessions, E/1998/22, paras 203, 228).

The CESCR also noted in 1998, in relation to one Middle Eastern state

The Committee stresses the importance of an independent judiciary, ensured not only by constitutional declaration, but in fact by guarantees accorded to magistrates, in order to ensure the exercise of all human rights, in particular economic, social and cultural rights, and the availability of effective remedies in case of violation (CESCR Annual Report on the $16^{\text {th }}$ and $17^{\text {th }}$ Sessions, E/ 1998/22, para 332).

And in relation to a North African state, the Human Rights Committee noted in 1995 that,

[a]lthough there is now in place an impressive array of State organs for the promotion and protection of human rights at various levels, the Committee notes that they have been concentrated exclusively within the executive branch of the Government. Consequently, it is not clear whether there are sufficiently independent mechanisms within the public administration and the judiciary to effectively monitor and enforce the implementation of existing human rights standards, including the investigation of abuses...The Committee is concerned about the independence of the judiciary. It is also concerned by the reports on harassment of lawyers who have represented clients accused of having committed political offences and of the wives and families of suspects (Human Rights Committee Annual Report A/50/40Vol.I, 1995, paras 85, 87). 
Rights to social and economic development. This category includes the right to just and favourable conditions of work (ICESCR, Articles 6-9) and the right to education (ICESCR, Articles 13-14). Both of these rights can be violated through distortion of government expenditure due to corruption. Large-scale, capital-intensive projects which provide more opportunities for corrupt behaviour may be preferred by corrupt officials to labour-intensive projects providing work or spending on essential public services, such as education (Jayawickrama 1998). Indeed, a recent empirical study has shown a negative correlation between corruption and government expenditure on education. Mauro examines the relationship between corruption and the composition of government expenditure, using corruption indices produced by a private firm, for a cross-section of countries. The hypothesis he tests is that corrupt governments will spend more public resources on items which provide more opportunities for corrupt behaviour and for which bribes can be efficiently collected and secrecy maintained (Mauro 1998). Mauro's findings confirm the hypothesis that corruption alters the composition of government expenditure. Specifically, the study shows that government spending on education is reduced. Mauro's paper presents 'evidence of a negative, significant, and robust relationship between corruption and government expenditure on education' (Mauro 1998:277). Mauro comments that

a possible interpretation of the observed correlation between corruption and government expenditure composition is that corrupt governments find it easier to collect bribes on some expenditure items than on others. Education stands out as a particularly unattractive target for rent-seekers, presumably in large part because its provision typically does not require high-technology inputs to be provided by oligopolistic suppliers (Mauro 1998:277-8).

When government expenditure on education is decreased, there are increased opportunities for violations of the right to education. In addition to the ICESCR, rights to education for children are protected under the Convention on the Rights of the Child. Where there is lack of resources to provide basic conditions for education, such as school buildings, textbooks and teachers, the access to and quality of education suffers and the right to education may be violated. Even where resources are provided, corrupt officials may divert these, and therefore the resources supplied will be inadequate or substandard. An example is provided by a project to extend primary schooling in a South Pacific nation which was affected by a corrupt official's misuse of some of the funds (Larmour 1997:9). UNICEF notes that the lack of basic education 'remains the most important single factor in protecting children from such hazards as exploitative child labour and sexual exploitation', which are violations of other human rights (UNICEF 1999:9). Decreased expenditure on education is a reason for concern, as previous literature has shown that educational 
achievement is an important determinant of economic growth (Mauro 1998), which is likely to be important for the protection of other human rights. Mauro notes that

[t]he question whether corruption affects the composition of government expenditure may have important implications. First, while the empirical literature has so far yielded mixed results on the effects of government expenditure and, in particular, its composition, on economic growth, most economists seem to think that the level and type of spending undertaken by governments do matter for economic performance. For example, even though cross-country regression work has not conclusively shown the existence of a relationship between government spending on education and economic growth, it has gathered robust evidence that school enrolment rates and educational attainment play a considerable role in determining economic growth (Mauro 1998:264-5).

The CESCR has noted the deleterious effects that corruption can have, inter alia, on the right to education and work, through distortion of government expenditure. It noted in 1999 in relation to a West African state that 'economic, social and cultural rights were hindered by the negative effects of widespread corruption on the functioning of government institutions' (CESCR Report on the $18^{\text {th }}$ and $19^{\text {th }}$ Sessions, E/1999/22, para 97). It also commented in 1998 with regard to a transition state

The Committee notes with apprehension that the process of transition to a democratic country with a market-based economy is being undermined by corruption, organized crime, tax evasion and bureaucratic inefficiency, resulting in inadequate funding for social welfare expenditure and for the payment of wages in the State sector (CESCR Report on the $16^{\text {th }}$ and $17^{\text {th }}$ Sessions E/1998/22, para 99).

The Committee noted that rights to food, health, nutrition, education and jobs were all affected due to the undermining of the social, economic and political structure in the transition state by, amongst other forces, corruption. Furthermore, in relation to a Middle Eastern state: ' $\mathrm{t}]$ he Committee notes with concern that a large proportion of resources necessary to finance social programs is diverted by corruption, which is pervading State organs and the sectors of the economy that are still under State control' (CESCR Report on the $16^{\text {th }}$ and $17^{\text {th }}$ Sessions E/1998/22, para 327).

Summary. This analysis indicates that, in many circumstances, corruption on the part of the state can lead to breaches of human rights. The analysis has sought only to give examples of how corruption can affect human rights and has attempted to provide supporting evidence where it is available. One of the difficulties mentioned above is linking corrupt behaviour with actual breaches of human rights. While this direct causal approach is useful for highlighting 
breaches, it should also be noted that breaches of human rights can also occur through indirect actions or omissions. It must also be recognised that corruption can have long-term effects which may not be as easily identifiable as being linked with resulting human rights violations, as well as short-term effects that are immediately recognised as breaches of human rights.

\section{Conclusion: possibilities of a human rights approach}

Taking a human rights approach to corruption highlights the fact that corruption is more than just misappropriation of money or abuse of power; corruption also has deleterious effects on people, which can lead to breaches of human rights. It acknowledges that corruption is a global problem, requiring global action and solutions. Giving corruption a 'human face' may lead to increased efficiency of anti-corruption efforts through better awareness of the effects of corrupt behaviour, increased calls for improved accountability and transparency in governments, and increased varieties of strategies that are available to combat corruption. The involvement of international organisations and institutions and non-governmental organisations in the process-many of whom already participate in human rights issues-may result in a strengthening of efforts towards human rights protection and anti-corruption, as these organisations put pressure on states to reform. Recognition of the effects of corruption as breaches of human rights as provided for under the ICCPR and the ICESCR may also lead to further attention being given to corruption within states by the respective Covenant Committees, which may be useful to highlight more explicitly the effects of corruption on human rights. Highlighting the human rights effects of corruption may serve to stimulate international concern and facilitate anti-corruption action. An element of this must be increased empirical study on the effects of corruption on human rights, which can only serve to stimulate further interest and action.

This chapter has highlighted that, while corruption is widely discussed in the literature and increasingly addressed in the international arena, a fundamental aspect of corruption has been left out of the discussion. The effect that corruption has on the fundamental human rights of people has been largely ignored, referred to only in the vague terms of 'development' and 'democracy'. The human rights discourse is an integral part of international law and needs to be incorporated into the international discussion and action against corruption. This chapter has highlighted instances where corruption has had, or may have, a deleterious effect on the rights of people. In examining the role and responsibility of states to respect, protect and fulfil human rights as guaranteed under the ICCPR and the ICESCR, the actions or omissions of states must be examined in regard to corrupt behaviour, as it has been argued 
that the tolerance of corruption by states through action or omission can result in breaches of human rights. States should be held accountable for this toleration. Utilising existing human rights discourse and mechanisms may be useful in the efforts to combat corruption to ensure human rights protection and accountability and transparency on the part of governments. The international community has an obligation to extend its anti-corruption efforts to the protection of human rights.

\section{Notes}

* The author acknowledges the Centre for Democratic Institutions, The Australian National University, for its financial support, Roland Rich and Hilary Charlesworth for extensive discussions on the ideas and content of this chapter and for reading early drafts, and Peter Larmour and Barry Hindess for providing feedback on drafts and ideas.

1 OAS members which have ratified the Convention are: Argentina, Bolivia, Chile, Colombia, Costa Rica, Dominican Republic, Ecuador, El Salvador, Honduras, Mexico, Nicaragua, Panama, Paraguay, Peru, Trinidad and Tobago, Uruguay, Venezuela. OAS members who have yet to ratify the Convention are: the United States, Suriname, Jamaica, Guatemala, Guyana, Haiti, Brazil, Canada, Bahamas (<http://www.OAS.org/juridico/english/Sigs/b-58.html>).

2 The OECD countries which have signed the OECD Convention are: Australia, Austria, Belgium, Canada, Czech Republic, Denmark, Finland, France, Germany, Greece, Hungary, Iceland, Ireland, Italy, Japan, Korea, Luxembourg, Mexico, the Netherlands, New Zealand, Norway, Poland, Portugal, Spain, Sweden, Switzerland, Turkey, the United Kingdom, the United States. The nonOECD countries who have signed the OECD Convention are: Argentina, Brazil, Bulgaria, Chile, and the Slovak Republic. The following countries have deposited their instruments of ratification/acceptance of the Convention with the Secretary-General of the OECD: Australia, Austria, Belgium, Bulgaria, Canada, Germany, Greece, Finland, Hungary, Iceland, Japan, Korea, Mexico, Norway, Slovakia, Sweden, the United Kingdom, the United States (<http:// www.oecd.org/daf/nocorruption/annex 2 .htm $>$, information correct up to 21 October 1999).

3 These countries were India, Argentina, Hungary, Morocco, Indonesia, Brazil, Poland, Nigeria, Philippines, Colombia, Russia, South Africa, South Korea, and Thailand (TI website).

4 The participants for the Limburg Principles came from Australia, the Federal Republic of Germany, Hungary, Ireland, Mexico, the Netherlands, Norway, Senegal, Spain, the United Kingdom, the United States, Yugoslavia, the United Nations Centre for Human Rights, the International Labour Organisation, the United Nations Educational, Scientific and Cultural Organisation, the World Health Organisation, the Commonwealth Secretariat, the sponsoring organisations, and four participants were members of the ECOSOC Committee on Economic, Social and Cultural Rights (Introduction, Limburg Principles, $H R Q 9$ (1987) 121; 285). The participants for the Maastricht Guidelines were 
from Austria, Canada, Germany, Ghana, Italy, the Netherlands, Norway, the Philippines, Poland, Sri Lanka, Switzerland, the United Kingdom, the United States, the International Commission of Jurists, the Commission on Human Rights, the International Labour Office, Habitat International Coalition, and the sponsoring organisations (Appendix A, Maastricht Guidelines, HRQ 20 (1998) 702-4; Dankwa et al. 1998).

5 The Limburg Principles on the Implementation of the International Covenant on Economic, Social and Cultural rights, adopted 8 January 1987, UN ESCOR, Comm'n on Hum. Rts., 43 ${ }^{\text {rd }}$ Sess., Agenda Item 8, UN Doc E/CN.4/1987/17/ Annex (1987). 